\title{
The effect of protein level in early feeding on yolk sac nutrient concentrations in chickens*
}

\author{
T. Wertelecki ${ }^{1}$ and D. Jamroz \\ Wroctaw Agricultural University, \\ Department of Animal Nutrition and Feed Quality \\ Chetmońskiego 38C, 51-630 Wroctaw, Poland
}

\begin{abstract}
Two hundred and forty one-day-old male Hubbard chickens were randomly assigned to three groups, each comprising 10 replicates of 8 birds. Chickens were fed isoenergetic diets containing 220 (HP), 200 (MP) or 185 (LP) g crude protein $\mathrm{kg}^{-1}$. The LP diet lowered the growth rate during the first 7 days of life and increased the rate of yolk sac resorption. In yolk sacs from groups fed MP and LP diets, the fat, proline, lysine and arginine contents decreased faster than in the HP group.
\end{abstract}

KEY WORDS: chickens, yolk sac, crude protein, fat, amino acids

\section{INTRODUCTION}

During the first days of life chickens can use nutrients from two sources, from yolk sac and from feed. The nutrients resorbed from yolk sac are used first for body growth and second, for development of the immune system (Wertelecki et al., 2001, 2003). The crude protein and amino acid contents and energy value of the consumed diet are important factors controlling chicken development in the early period of life (Stringhini et al., 2002). In the present study, the effects of feeding chickens diets differing in crude protein and amino acid levels during the first week of life on the resorbtion rate and the content of protein, fat and amino acids in the yolk sac were examined.

\section{MATERIAL AND METHODS}

Two hundred and forty one-day-old male Hubbard chickens were randomly

\footnotetext{
* Supported by the State Committee for Scientific Research, Grant No. 3 P06Z 03622

${ }^{1}$ Corresponding author: e-mail: tomekw@zoo.ar.wroc.pl
} 
assigned to three groups, each comprising 10 replicates of 8 birds, maintained in cages. Three diets with an energy value of $12.5 \mathrm{MJ} \mathrm{ME} \mathrm{kg}^{-1}$ varying in crude protein content from 220 (HP), 200 (MP) to $185 \mathrm{~g} \mathrm{~kg}^{-1}$ (LP) were prepared. Diets were based on maize $(510-620 \mathrm{~g} / \mathrm{kg})$, soyabean meal $(300-400 \mathrm{~g} / \mathrm{kg}$ ) and soya oil (33-51 g kg). On days 1 (before the first feeding), 3, 5 and 7 days of life, 20 birds from each group were weighed, killed, yolk sacs were removed. Yolk sac contents were pooled by 4 , homogenized and lyophilized. The growth rate (GR) in groups was calculated according to the following equation:

$$
\mathrm{GR}=[(\mathrm{FBW}-\mathrm{IBW}) /(0.5 \times(\mathrm{IBW}+\mathrm{FBW}) \times \text { days })] \times 100
$$

where: IBW - initial body weight; FBW - final body weight.

In yolk sac contents, total nitrogen (crude protein as $\mathrm{N} \times 6.25$ ) and crude fat were determined by standard methods (AOAC, 1995), while amino acid concentrations, on a Mikrotechna AAA-339 apparatus. The results were subjected to oneway analysis of variance with the use of the Statgraphic System 1985-1995.

\section{RESULTS AND DISCUSSION}

The growth rate during the first 7 days of life was lower, while the loss of yolk sac weight higher $(\mathrm{P}<0.05)$ during first 3 days of life in the group fed the LP diet in comparison with the other two groups (Table 1). This is in agreement with the results of Stringhini et al. (2002). Very high variance among birds was observed in crude protein, crude fat and amino acid disappearance, however in all groups during the first 3 days of life, more fat than protein was absorbed from the yolk sac, as the fat content in the yolk sac was significantly lower in group MP on day 3 and in both MP and LP groups on day 5 than in the HP group (Table 2). The rate of crude protein disappearance from the yolk sac did not differ greatly, in contrast with our previous studies (Wertelecki et al., 2001, 2003).

Table 1. Initial body weight, growth rate and yolk sac weight

\begin{tabular}{lcccc}
\hline \multirow{2}{*}{ Item } & \multicolumn{3}{c}{ Dietary treatment } & \multirow{2}{*}{ SEM } \\
\cline { 2 - 4 } & HP & MP & LP & \\
\hline Initial body weight, g & 37.24 & 38.96 & 40.21 & 1.55 \\
GR from 1 to 7 day & $16.01^{\mathrm{a}}$ & $15.68^{\mathrm{a}}$ & $14.64^{\mathrm{b}}$ & 2.03 \\
Initial yolk sac weight, g & 3.64 & 3.64 & 4.03 & 1.18 \\
Yolk sac weight loss 1 to 3 day, g & $2.12^{\mathrm{a}}$ & $2.27^{\mathrm{a}}$ & $2.73^{\mathrm{b}}$ & 0.85 \\
$\quad 3$ to 5 day, g & $1.03^{\mathrm{a}}$ & $0.88^{\mathrm{ab}}$ & $0.75^{\mathrm{b}}$ & 0.39 \\
$\quad 5$ to 7 day, g & $0.03^{\mathrm{a}}$ & $0.11^{\mathrm{b}}$ & $0.23^{\mathrm{c}}$ & 0.38 \\
\hline a,b - values in rows with different superscripts differed significantly at $\mathrm{P}<0.05$ &
\end{tabular}


Table 2. Crude protein (CP), crude fat (CF), g/100 $\mathrm{g}^{-1}$ and amino acids (g/16 g N) in yolk sac content

\begin{tabular}{|c|c|c|c|c|c|c|c|c|c|c|c|c|}
\hline Day & y Group & $\mathrm{CP}$ & $\mathrm{CF}$ & Pro & $\begin{array}{l}\text { Met } \\
+ \text { Cys }\end{array}$ & Ile & Leu & His & Lys & Arg & Try & Thr \\
\hline 1 & & 24.7 & 18.3 & 3.20 & 5.90 & 3.10 & 7.20 & 2.90 & 7.30 & 6.20 & 1.50 & 3.70 \\
\hline \multirow{4}{*}{3} & HP & 24.7 & $13.6^{\mathrm{a}}$ & $4.04^{\mathrm{a}}$ & 5.94 & 3.45 & $6.44^{\mathrm{a}}$ & 3.95 & $8.38^{\mathrm{a}}$ & $6.39^{\mathrm{a}}$ & $1.43^{\mathrm{a}}$ & 3.92 \\
\hline & MP & 26.5 & $10.2^{\mathrm{b}}$ & $3.33^{\mathrm{b}}$ & 6.15 & 3.35 & $7.13^{\mathrm{ab}}$ & 3.29 & $6.51^{\mathrm{b}}$ & $5.47^{\mathrm{b}}$ & $1.40^{\mathrm{a}}$ & 4.11 \\
\hline & LP & 24.1 & $13.0^{\mathrm{a}}$ & $3.59^{\mathrm{b}}$ & 5.10 & 3.29 & $8.00^{\mathrm{b}}$ & 3.49 & $7.40^{\mathrm{ab}}$ & $5.96^{\mathrm{b}}$ & $1.17^{\mathrm{b}}$ & 4.02 \\
\hline & SEM & 1.8 & 2.2 & 0.36 & 0.76 & 0.08 & 0.78 & 0.34 & 0.94 & 0.46 & 0.14 & 0.10 \\
\hline \multirow{4}{*}{5} & HP & $16.5^{\mathrm{a}}$ & $16.7^{\mathrm{a}}$ & $3.46^{\mathrm{a}}$ & $4.62^{\mathrm{a}}$ & 3.12 & 8.10 & $4.02^{\mathrm{a}}$ & 8.94 & 7.65 & 1.17 & 3.61 \\
\hline & MP & $16.4^{\mathrm{a}}$ & $14.8^{b}$ & $3.27^{\mathrm{ab}}$ & $4.02^{\mathrm{a}}$ & 3.12 & 6.97 & $4.38^{\mathrm{ab}}$ & 9.41 & 6.79 & 1.12 & 3.80 \\
\hline & LP & $19.2^{\mathrm{b}}$ & $13.6^{\mathrm{b}}$ & $3.09^{b}$ & $2.93^{b}$ & 3.23 & 7.60 & $4.61^{b}$ & 9.70 & 6.76 & 1.16 & 3.77 \\
\hline & SEM & 0.9 & 0.9 & 0.19 & 0.83 & 0.06 & 0.56 & 0.30 & 0.38 & 0.51 & 0.03 & 0.10 \\
\hline \multirow{4}{*}{7} & HP & 12.8 & 12.2 & $3.00^{\mathrm{a}}$ & 4.23 & $3.19^{\mathrm{a}}$ & 7.11 & 4.66 & $9.03^{\mathrm{a}}$ & 7.86 & 1.00 & $3.40^{\mathrm{a}}$ \\
\hline & MP & 16.5 & 12.1 & $3.55^{\mathrm{ab}}$ & 3.23 & $3.10^{\mathrm{a}}$ & 6.52 & 4.95 & $4.74^{\mathrm{b}}$ & 5.58 & 0.75 & $3.03^{\mathrm{a}}$ \\
\hline & LP & 13.5 & 13.7 & $4.75^{b}$ & 5.34 & $4.71^{\mathrm{b}}$ & 9.24 & 4.43 & $9.93^{\mathrm{a}}$ & 7.30 & 0.96 & $6.03^{b}$ \\
\hline & SEM & 0.9 & 0.8 & 0.90 & 0.98 & 0.90 & 1.43 & 0.26 & 2.77 & 1.19 & 0.14 & 1.63 \\
\hline
\end{tabular}

The amino acid composition of yolk sac protein differed in each period of life. On day 3, the proline, lysine and arginine contents were lower in the groups fed diets with a reduced protein content, while the content of tryptophan was lower only in the LP group (Table 2). A similar tendency was observed for proline, methionine and cystine, while the histidine content increased on day 5 of life $(\mathrm{P}<0.05)$. The faster disappearance proline, lysine and arginine from protein yolk sacs of chickens fed the LP diets on 3 day of life points to a higher requirement for these amino acids in early nutrition (Noy et al., 1996; Wertelecki et al., 2001). On day 7 of life, the content of proline, isoleucine and threonine was higher in group LP $(\mathrm{P}<0.05)$.

\section{CONCLUSIONS}

A reduced level of protein in early nutrition stimulates the rate of resorption of the yolk sac contents. The changes in amino acid composition of yolk sac protein may help in the proper balancing of the amino acid composition of pre-starter diets.

\section{REFERENCES}

AOAC, 1995. Official Methods of Analysis, Association of Official Analytical Chemists. $16^{\text {th }}$ Edition. Arlington, VA

Noy Y., Uni Z., Sklan D., 1996. Routes of yolk utilization in the newly-hatched chick. Brit. Poultry Sci. 37, 88-101 
Stringhini J.H., Andrade M.L., Xavier S., Leonardo N., Andrade L., Cafe M., 2002. Protein and amino acid supplementation levels for broilers in pre-starter ration (1 to 7 days). Proceedings of $11^{\text {th }}$ European Poultry Conference. Bremen (Germany) (CD source)

Wertelecki T., Jamroz D., 2001. The changes in chemical composition of yolk sacs in chicks fed the mixtures differed in protein level. Zesz. nauk. PTZ 57, 131-143

Wertelecki T., Jamroz D., 2003. Amino acid composition of yolk sac content and ideal protein concept in feed. Zesz. nauk. PTZ 68, 4, 105-119

\section{STRESZCZENIE}

Zmiany koncentracji składników pokarmowych woreczków żóltkowych kurcząt w zależności od żywienia mieszankami o zróżnicowanej zawartości białka ogólnego

Dwieście czterdzieści jednodniowych kogutków Hubbard, podzielonych na 3 grupy po 10 powtórzeń, po 8 piskląt w każdej, żywiono dietami o trzech poziomach białka: $220 \mathrm{~g} \mathrm{~kg}^{-1}$ (HP), 200 (MP) lub $185 \mathrm{~g} \mathrm{~kg}^{-1}$ (LP). Żywienie dietą LP istotnie obniżyło tempo przyrostu masy ciała w pierwszych 7 dni życia i spowodowało szybszą resorpcję woreczków żółtkowych. W grupie żywionej dietami MP i LP stwierdzono szybszy ubytek tłuszczu z woreczków, a także mniejszą zawartość proliny, lizyny i argininy w białku woreczków. 